\title{
TEWISH FACTION AT THE THIRD SEIMAS OF LITHUANIA IN 1926-1927: ON THE WAY TO THE IDENTITY CRISIS
}

\section{Saulius Kaubrys}

Vilnius University, E-mail: saulius.kaubrys@if.vu.lt

\begin{abstract}
:
The article discusses the characterisation of the activity of the Jewish faction before the third Seimas and its actions at the short-lived Third Seimas. Due to the circumstances that formed at the Constituent Seimas, the Jewish faction belonged to the Seimas opposition at the First and Second Seimas. The results of the election to the Third Seimas in 1926 provided the Jewish faction with the opportunity to become a constituent part of the ruling coalition. The requirements imposed on the large partners of the coalition reflected both the aspiration to correct "the mistakes" made by the former Seimas with respect to the Jewish community and the aspiration to form the perspective of new possibilities. The relationships with the coalition partners went through two different phases - until the coup d'état of December 1926 and after it. The former link of solidarity and loyalty was replaced with a collective behaviour of adaptation, which permeated the actions of the factions of other ethnic minorities. Work experience in solving the Jewish problems at the Third Seimas is not wide and long.
\end{abstract}

\section{Rezumat:}

Articolul realizează o caracterizare a activității grupării evreiești înainte de a treia Seimas și din cursul scurtei activități a acesteia. Datorită circumstanțelor care au condus la Seimas constituantă, gruparea evreiasă făcuse parte din opoziție in cadrul primelor două Seimas. Rezultatul alegerilor pentru a treia Seimas din 1926 a oferit grupării evreiești șansa de a deveni o parte componentă a coaliției conducătoare. Cerințele impuse partenerilor mai mari din coaliție au reflectat atât aspirația de a corecta "greșelile" realizate de anterioarele Seimas cu privire la comunitatea evreiască, cât și pe aceea de a deschide perspectiva unor noi posibilități. Relația cu partenerii de coaliție a trecut prin două etape distincte - până la lovitura de stat din decembrie 1926 și după aceea. Fosta legătură de solidaritate și loialitate a fost inlocuită cu un comportament colectiv de adaptare, care a impregnat acțiunile grupărilor altor minorități etnice. Activitatea depusă pentru rezolvarea problemelor evreiești în cadrul celei de-a treia Seimas nu este consistentă și nici de durată. 
Keywords: Third Seimas, Jewish faction, elections, Peasant Popular Union, Social Democrats

\section{The Jewish faction at the Lithuanian Seimas in 1920-1926: on the margin of political opposition}

The Independence of Lithuania declared in 1918 opened up new possibilities for society and its self-expression. The characterisations of the election campaign to the Seimas of Lithuania and the activity of the members elected to them became examples of the political school of society - both of the prevailing majority of the Lithuanians and of the ethnic groups. Thirty one lists of candidates, including 5 lists of the representatives of the ethnic groups, were nominated in six constituencies in the election to the Constituent Seimas on 14-16 April 1920. The only list of the Jewish candidates - the Jewish People's Unification received 44709 votes of the electors, which accounted for $52.74 \%$ of all the votes received by the lists of the ethnic groups. Six persons of Jewish nationality were elected to the Constituent Seimas - Ozer Finkelshtein, Naftl Fridman, Avrom Popel, Nachman Rachmilevich, Šimšn Rozenbaum and Maks Soloveichik.

During the election to the First Seimas that took place at the end of 1922, 13 lists of the ethnic minorities were nominated, including 3 lists of the Jews. The Jewish people's party Achdus received 16841 votes, the Zionist group For the Nation and Autonomy was given 34697 votes and the Committee of Jewish People gained 3619 votes. The election was held in accordance with the new regulation approved by the Law on Elections of the Seimas on 19 July 1922, which was partly unfavourable to the lists of the "minorities". Only three Jewish candidates were elected to the first Seimas -- Lev Garfunkel, Joel Bruck, and Josel Berger.

In the elections to the Second Seimas held on May 12-13 1923, eight lists of the candidates of the ethnic minorities, including two "purely" Jewish lists were submitted (the Jewish People's Party Achdus received only 53 votes, the list of the Jewish workers obtained 1048 votes). Nonetheless, the joint list of the United Minorities (Jews, Germans, Russians, and Byelorussians) enjoyed the greatest success, it obtained as many as 99379 electors' votes. Seven Jewish representatives were elected to the second Seimas - O. Finkelshtein, L. Garfunkel, Yosef Kaganeman, Jacob Robinzon, Josel Roginski, S. Rozenbaum, and Sulim Volf). 
The results of the elections to the Seimas (the Constituent Seimas, the first and the Second Seimas) testify to the fact that the Jewish representatives outnumbered the representatives of other ethnic groups (see Table No. 1).

Table No.1. Representatives of national minorities in Lithuanian Seimas (1920-1926).

\begin{tabular}{|l|c|c|c|c|c|}
\hline \multicolumn{1}{|c|}{$\begin{array}{c}\text { Title of } \\
\text { Seimas }\end{array}$} & $\begin{array}{c}\text { Elected in } \\
\text { total }\end{array}$ & Jewish & Polish & Russian & German \\
\hline $\begin{array}{l}\text { Consistuent } \\
\text { Seimas }\end{array}$ & 112 & 6 & 3 & - & 1 \\
\hline First Seimas & 78 & 3 & 2 & - & - \\
\hline Second Seimas & 78 & 7 & 4 & 1 & 2 \\
\hline
\end{tabular}

The Lithuanian historian Arkadijus Bliuminas, having studied the characteristics of the activity of the Jewish faction, stated that the course followed by the Jewish faction at the Constituent Seimas was referred to as sustaining-creating, as stagnating in the First Seimas and as protectingdefending in the second Seimas ${ }^{1}$. The model of the political course of the Jewish faction offered by the said author most probably should be corrected. For example, it is hardly possible to refer to the activity of the Jewish representatives in the First Seimas as stagnant, all the more so that the latter Seimas functioned only for several months and none of the factions had time to accomplish anything particular.

The quantitative and qualitative analysis of the utterances of the members of the Jewish faction in the Seimas leads us to the following supposition:

1) The Jewish representatives were not just passive observers though restricted by objective circumstances (belonging to the minority of the Seimas), within the bounds of possibility, they sought to ensure more favourable conditions for the development of the Jewish community. The rostrum of the Seimas became the place of publicising their interests. The Jewish politicians were made to manoeuvre and form a coalition now with the right-wing parties now with the left-wing ones². According to the interwar leading figure in law Mykolas Riomeris, the Jews in the Constituent

\footnotetext{
1 Arkadijus Bliuminas, Žydu frakcija Lietuvos Seimuose 1920-1927 m. (Vilnius, 2003), 68.

2 Vladas Sirutavičius, "Valdžios politika žydų atžvilgiu", in Lietuvos žydai. Istorinè studija, eds. Vladas Sirutavičius, Darius Staliūnas, Jurgita Šiaučiūnaitė-Verbickienė (Vilnius, 2012), 306.
} 
Seimas "most often adhered to the populists [Peasant Popular Union - S.K.] and were inclined to support them in the state employment" 3 .

2) The Jewish faction most likely also had to admit that their representation was partly inefficient. For example, during the entire term of office of the Constituent Seimas (1920-1922 m.) O. Finkelshtein "did not speak in public from the Seimas rostrum. He personally, or together with members of other factions, submitted interpellations to the highest public authorities to which they received answers but they did not become amendments to the laws to be considered" 4 . N. Fridman, in the Commission on the Land Reform of the same Seimas, "defended the rights that belonged to the Jews to land, however, the attempts to legalise all hat were fruitless" During the whole period of work of the Constituent Seimas a member of the Jewish faction N. Rachmilevich "submitted 30 amendments, proposals, editorial remarks, but their absolute majority was rejected $<\ldots>^{\prime \prime} 6$.

3) The Jewish faction underwent the fate of unfavourable decisions related to the development of the Jewish community in the same way (for example, on 3 September 1924, Second Seimas of Lithuania issued a resolution according to which shops had to be closed on Sundays and during Catholic festivals, in 1925, the spread of the Jewish national autonomy was suspended) 7 . Most probably there was not always unity inside the Jewish faction itself (for example, there were disagreements about the proposals in the draft of the Constitution) $)^{8}$.

\section{Election to the Third Seimas and becoming a partner in the ruling political coalition}

The election to the Seimas that took place on 8-10 May 1926 reflected the moods of the society that was disappointed with the policy of the Christian Democratic bloc and, most probably, its greater disunity. For example, 31 lists were nominated in the election to the Constituent Seimas,

\footnotetext{
${ }^{3}$ Mykolas Rėmeris, Lietuvos konstitucinès teisés paskaitos (Vilnius, 1990), 139.

4 Eglè Bendikaitè, "Finkelšteinas Ozeris", in Lietuvos Steigiamojo Seimo (1920-1922 metu) nariu biografinis žodynas (Vilnius, 2006), 141-142.

5 Bendikaitè, "Fridmanas Naftalis", Lietuvos Steigiamojo Seimo, 144.

${ }^{6}$ Bendikaitė Eglè, "Rachmilevičius Nachmanas", Lietuvos Steigiamojo Seimo, 293.

${ }^{7}$ Liudas Truska, Vareikis Vygantas, Holokausto prielaidos. Antisemitizmas Lietuvoje XIX a. antroji pusé - 1941 m. birželis (Vilnius, 2004), 50; S. Atamukas, Lietuvos žydu kelias nuo XIV amžiaus iki XX a. pabaigos (Vilnius, 1998), 130.

8 See: "Žydų bendruomenių organizavimo klausimai", Savivaldybè 1 (1926): 17. 30
} 
and 55 lists of candidates were nominated in the election to the Third Seimas 9 . The Jewish community chose from two lists: the United democratic and Religious-economic ones (Achdut and others) ${ }^{10}$.

Active propaganda-preparatory work was carried out. For example, on 18 April 1926, a meeting of the Jewish residents inspired by the representatives of the list of the Jewish Democratic Unification took place in Panevėžys. During the meeting, which was attended by approximately 600 people, the member of the Seimas O. Finkelshtein took the floor and spoke about the future election and the tasks of the Jewish community ${ }^{11}$. On 30 April 1926, a pre-election meeting of the Jews took place again in Panevéžys in which the member of the Seimas J. Robinzon participated ${ }^{12}$.

Nevertheless, it seems that the election to the Third Seimas dispelled the myth that was created in society about the seeming unity of the Jews ${ }^{13}$. The Jewish Democratic Unification received 47142 votes, the economicreligious list of the Jews obtained 16702 votes $^{14}$. The Jewish representatives received only three seats in the Seimas - O. Finkelshtein, L. Garfunkel and J. Robinzon became parliamentarians.

The results of the election to the Third Seimas testified to a change in the public opinion - disappointment with the former policy of the Christian Democratic bloc of 1923-1926 and a more obvious support of the left-wing parties - the Social Democrats and the Peasant Popular Union. Having received the largest number of votes (22), the latter undertook the initiative to form the ruling coalition, which under the circumstances of that time was impossible without the Social Democrats and the third party - the participation of the representatives of ethnic minorities. Most likely this choice was determined by both the similarity of ideological positions and practical aspects of the formation of the coalition (there was no possibility of a wider choice). A coalition agreement between the large partners - the

\footnotetext{
9 Vytautas Andriulis, Mindaugas Maksimaitis, Vytautas Pakalniškis, Justinas Sigitas Pečkaitis, Antanas Šenavičius, Lietuvos teisés istorija (Vilnius, 2002), 342.

10 Bliuminas, 58; Liekis Šarūnas, A State within a State? Jewish autonomy in Lithuania 1918-1925 (Vilnius, 2003), 201.

11 Report of the Governor of the town and district of Panevėžys of 19 April 1926 to the Department of Citizens Protection, Lithuanian Central State Archives, Fund 404, Inv.1, file $263,1125$.

12 Report of the Governor of the town and district of Panevezzys of 9 May 1926 to the Department of Citizens Protection, ibid., 1. 157.

${ }^{13}$ Liudas Truska, Lietuviai ir žydai nuo XIX a. pabaigos iki 1941 m. birželio (Vilnius, 2005), 75.

${ }^{14}$ Lietuvos statistikos metraštis 1924-1926, vol. 1, 84-89.
} 
Lithuanian Peasant Popular Union and the Lithuanian Social Democratic Party seems to have not been properly balanced - the members of the Peasant Popular Union most likely had gone to too great compromises and failed to foresee their possible consequences ${ }^{15}$.

The minor partners in the future coalition - the representatives of ethnic minorities, including the representatives of the Jews, formulated their requirements. The analysis of the proposal package made by the Jews leads us to the following supposition:

1) it contained the requirements of three types: in "the sphere of the national rights", "in the sphere of the general civil rights" and "in the sphere of economic issues". The perspective of their implementation from the point of view of time is divided into the "near ("urgent", "in the first session") and the "distant" ones ("with the passing of time", "after the first session"). According to the manner of their implementation, two possibilities of their realisation are provided for - "by way of giving the law" and "administratively".

2) the contents of the requirements reflected the aspirations of the Jewish faction: a) reconstructive aspirations (e.g., to abolish the Law on Jewish National Communities"); b) the continuous aspirations ("a loyal fulfilment of the promises given [...] to the League of Nations on 12 May 1922); c) the aspirations ensuring a positive development of the Jewish community (e.g. an increase in the subsidies granted to the Jewish secondary schools and others). Some of the latter requirements were rather petty (for example, solving "the issue of Kaunas slaughter house", "free admission of the Jews to the civil service").

The requirements of the Jewish faction concerning the issue of education submitted to the Lithuanian Social Democratic faction urged the authorities to recognise the dismissals of the teachers on account of a lack of qualification as unlawful. It was required to increase subsidies to secondary schools, to allow foreign teachers enter Lithuania, to invite a professor to the University to teach a course in Jewish studies, etc. The answer of 12 June 1926 to the Jewish faction stated that the majority of the requirements would be fulfilled, whereas others were left open (for example, the University, as an

\footnotetext{
15 Mindaugas Tamošaitis, „III Seimas (1926-1927)“, in Lietuvos Respublikos Seimu I (1922-1923), II (1923-1926), III (1926-1927), IV (1936-1940) nariu biografinis žodynas (Vilnius, 2007), 140. 32
} 
autonomous institution, had an exceptional status, and it was impossible to get round this institution directly).

It seems that the package in the form of the requirements concerning educational issues was the most acceptable to both largest partners. The Chairman of the Peasant Popular Union faction Zigmas Toliušis stated later at a general meeting of the representatives of the party held on 6-8 December 1926 that he had found it easiest to come to an agreement with the Jews because "there is no need to interfere with their cultural life (there was no hope of Lithuanianising them) and the faction gave them freedom in cultural and religious things. No attempts were made to come to an agreement on the economic matters altogether since they represented merchants, the faction was a supporter of co-operative societies"16. The Lithuanian Peasant Popular Union faction had also promised to go through the Law on Education again because it was not only the Jews who demanded that - there were more similar requests in society.

It is thought that both the large and the minor partners in the coalition (the Jews belonged to the latter) needed one another. If the former had no other possibility of choice, the "minor" ones (Jews, Germans, Poles) had a historical chance to be in political power.

\section{Test by power and durability of the coalition}

During the term of office of the Third Seimas 78 sittings took place. Members of the Jewish faction took the floor 15 times (O. Finkelshtein - 7, J. Robinzon - 5, L. Garfunkel - 3 (see Table No.2).

Table No.2. Speeches of the representatives of Jewish faction, 1926.

\begin{tabular}{|l|l|c|}
\hline \multicolumn{1}{|c|}{ Data } & \multicolumn{1}{|c|}{ Title } & Speaker \\
\hline 2 June, 1926 & $\begin{array}{l}\text { Speech of the Chairman of the } \\
\text { Century }\end{array}$ & O. Finkelštein \\
\hline 9 June, 1926 & $\begin{array}{l}\text { Report of the Commission on } \\
\text { Commissions }\end{array}$ & O. Finkelštein \\
\hline 22 June, 1926 & Draft Law on Amnesty's & O. Finkelštein \\
\hline
\end{tabular}

\footnotetext{
16 Minutes of the Meeting of the representatives of the Lithuanian Peasant Popular Union of 6-8 December 1926, Wroblewski Library of the Lithuanian Academy of Sciences, Manuscript Department, F. 199-41, 1. 82-83.
} 


\begin{tabular}{|c|c|c|}
\hline 23-24 June, 1926 & $\begin{array}{l}\text { Discussions about the declaration of } \\
\text { the Cabinet of Ministers }\end{array}$ & J. Robinzon \\
\hline 2 July, 1926 & Draft Law on Amnesty's & O. Finkelštein \\
\hline 2 July, 1926 & Draft Law on Amnesty's & J. Robinzon \\
\hline 18 July, 1926 & $\begin{array}{l}\text { Interpellation concerning the financial } \\
\text { policy of the Cabinet of Ministers }\end{array}$ & L. Garfunkel \\
\hline 5 October, 1926 & $\begin{array}{l}\text { On Amending the Law on the Patient } \\
\text { Account }\end{array}$ & O. Finkelštein \\
\hline $\begin{array}{l}5 \text { November, } \\
1926\end{array}$ & $\begin{array}{l}\text { Change in the staff of the Ministry of } \\
\text { the Interior }\end{array}$ & O. Finkelštein \\
\hline $\begin{array}{l}12 \text { November, } \\
1926\end{array}$ & Law on the State Budget & L. Garfunkel \\
\hline $\begin{array}{ll}2 & \text { December, } \\
1926 & \end{array}$ & $\begin{array}{l}\text { The State Budget of the Republic of } \\
\text { Lithuania of } 1927\end{array}$ & O. Finkelštein \\
\hline $\begin{array}{ll}10 & \text { December, } \\
1926 & \end{array}$ & $\begin{array}{l}\text { Amendment to the Law on Public } \\
\text { Holidays and Rest }\end{array}$ & L. Garfunkel \\
\hline $\begin{array}{ll}14 & \text { December, } \\
1926 & \end{array}$ & $\begin{array}{l}\text { The State Budget of the Republic of } \\
\text { Lithuania of } 1927\end{array}$ & J. Robinzon \\
\hline $\begin{array}{ll}30 & \text { December, } \\
1926 & \\
\end{array}$ & $\begin{array}{l}\text { The State Budget of the Republic of } \\
\text { Lithuania of } 1927\end{array}$ & J. Robinzon \\
\hline $\begin{array}{ll}1 & \text { December, } \\
1926 & \end{array}$ & $\begin{array}{l}\text { The State Budget of the Republic of } \\
\text { Lithuania of } 1927\end{array}$ & J. Robinzon \\
\hline
\end{tabular}

Due to natural reasons the routine practice of the short-lived Third Seimas was not "saturated" with the issues of the Jewish problems. Nevertheless, the contextual creation of laws provided the Jewish faction with chances to publicise general interests of its electorate. This possibility perhaps presented itself most clearly when the amendments to the Law on Public Holidays and Rest was considered (the Law adopted at the Second Seimas established practice of possible working days that was unfavourable to the Jews). The contents of the motifs concerning the Law presented by L. Garfunkel was discussed at the sitting held on 10 December 1926 both disagreeing to its essence ("here we should not think that having amended that Law our economic situation will improve", Antanas Šmulkštys) ${ }^{17}$, and not recognising the importance of the proposals put forward ("merchants

17 The 57th sitting of 10 December 1926, Records of the Third Seimas 1926-1927 (Kaunas, 1927), 13. 34 
Jews who find this law especially uncomfortable do not constitute a larger part of society" Petras Radzevičius) ${ }^{18}$, and also indiscreetly seeing personal reasons ("small merchants are abolishing and Mr. Garfunkel and Mr. Finkelshtein are supporting that draft law" Antanas Endziulaitis) ${ }^{19}$. Nonetheless, a relative victory was won - the law was recognised as worth being considered. At the sitting held on 12 November 1926, when considering the draft law on the State Budget, L. Garfunkel appealed to the cause that determined the abolishment of the Jewish national autonomy in 1924, when the laws of the office of the Minister for Jewish Affairs were still in effect no funds were allocated to that institution ${ }^{20}$. Thereby, given the example of the dichotomy of the operation of that law and its implementation the authorities were urged to avoid similar mistakes in the future.

The actions of the Jewish faction as an ally of the large partners of the coalition, which was linked by internal obligations, are to be assessed from several perspectives. First, as the actions of loyal associates. For example, at the sitting held on 23-24 June 1926 the Jewish faction expressed confidence in the Cabinet of Ministers'1; at the sitting held on 5 November 1926, the Jewish representatives voted unanimously for the ratification of the agreement between the Republic of Lithuania and the USSR 22 ; at the sitting of 3 December 1926 they supported the formula for the answer to the interpellation put forward by Pranas Dailide (the Peasant Popular Faction), Kipras Bielinis (the Social Democratic Faction) and J. Robinzon that was related to the demonstration in Kaunas on 21 November $1926^{23}$. Second, as non-solidarity actions. For example, at the meeting held on 21 July 1926, when the draft of the Peasant Popular Faction on supplementing and amending the estimate of the state expenditures was discussed (concerning the funds allocated to the clergy for the services of registration of marriages). The Seimas disapproved of the latter proposal. It seems that the Jewish representatives were among those who disapproved of $i^{24}$. Nonetheless,

\footnotetext{
18 Ibid, 5.

19 Ibid., 10.

20 The 42nd sitting of 12 November 1926, Records of the Third Seimas 1926-1927 (Kaunas, 1927), 1819.

21 The 12th sitting of 23-24 June 1926, ibid., 30-31.

22 The 40th sitting of 5 November 1926, ibid., 31.

23 The 53rd sitting of 3 December 1926, ibid., 27.

24 The 25th sitting of 21 July 1926, ibid., 43; Tamošaitis, 158.
} 
there were more manifestations of non-solidarity after the coup d'état of 17 December 1926. For example, at the sitting of 31 December 1926, when considering the 1927 budget, the representatives of the Social Democrats and the Peasant Popular Union said that they were going to vote in favour of, whereas the Jewish representatives (as well as those of the Poles and Germans) said they would abstain ${ }^{25}$. In 1927, at the remaining sitting of the Seimas (on 12 April the Seimas was dissolved) the representatives of the Jewish faction did not speak at all and did not express any support of the partners in the former coalition - for example, when considering the declaration of the new Cabinet of Ministers on 3 March 1927 and on 8 March 1927 too. It is true, Rudolf Kinder, when speaking at that sitting on behalf of the minority factions announced that they were not going to take part in the confidence vote for the Cabinet of Ministers. It is thought that such a passive attitude of the Jews (like that of the representatives of other minority groups) cannot be assessed as integral.

\section{Conclusions}

The results of the election to the Third Seimas provided the Jewish faction with the historical chance to become a constituent part of the ruling political coalition. The package of the requirements to the future partners in the coalition was partly rational inspired from the programme of this minority, however, failing to avoid certain worthless stuff and "dirt". The presence of the representatives of the Jewish faction in the coalition is characterised by two different forms of collective behaviour - relatively active and passive. The sequence of events that formed in the course of the 1926 coup d'etat became the dividing line. The routine practice of the Seimas legislation, due to both its transience and the priorities of solving general state topical issues gave few chances to publicising and defending the Jewish problems. The reserved position of the Jewish faction with respect to the former larger partners in the coalition in 1927 most probably was a joint coordinated attitude of the factions of ethnic minorities, which can be treated as partly inconsistent.

25 The 67th sitting of 31 December 1926, Records of the Third Seimas 1926-1927, 16. 


\section{References:}

\section{A. Archives:}

Lithuanian Central State Archives, Fund 404, Inv.1, file.263.

\section{B. Books and articles:}

"Žydų bendruomenių organizavimo klausimai". Savivaldybe 1 (1926). Andriulis, Vytautas, Mindaugas Maksimaitis, Vytautas Pakalniškis, Justinas Sigitas Pečkaitis, Antanas Šenavičius. Lietuvos teisès istorija. Vilnius, 2002.

Atamukas S. Lietuvos žydų kelias nuo XIV amžiaus iki XX a. Pabaigos. Vilnius, 1998.

Bliuminas, Arkadijus. Žydu frakcija Lietuvos Seimuose 1920-1927 m. Vilnius, 2003.

Liekis Šarūnas. A State within a State? Jewish autonomy in Lithuania 1918-1925. Vilnius, 2003.

Lietuvos Respublikos Seimu I (1922-1923), II (1923-1926), III (1926-1927), IV (1936-1940) narių biografinis žodynas. Vilnius, 2007.

Lietuvos statistikos metraštis 1924-1926, vol. 1.

Lietuvos Steigiamojo Seimo (1920-1922 metu) nariu biografinis žodynas. Vilnius, 2006.

Rėmeris, Mykolas. Lietuvos konstitucinès teisés paskaitos. Vilnius, 1990.

Sirutavičius, Vladas. „Valdžios politika žydu atžvilgiu.“ In Lietuvos žydai. Istorine studija. Eds. Vladas Sirutavičius, Darius Staliūnas, Jurgita Šiaučiūnaitè-Verbickienè. Vilnius, 2012.

Trečiojo Seimo stenogramos 1926-1927. Kaunas, 1927.

Truska, Liudas, Lietuviai ir žydai nuo XIX a. pabaigos iki $1941 \mathrm{~m}$. Birželio. Vilnius, 2005.

Truska, Liudas, Vygantas Vareikis. Holokausto prielaidos. Antisemitizmas Lietuvoje XIX a. antroji puse - 1941 m. Birželis. Vilnius, 2004. 